\title{
METHODS OF DISSEMINATING DANCE IN EUROPEAN MUSEUMS
}

\author{
Tone ERLIEN \\ Choreomundus Master Programme - International Master in Dance Knowledge, Practice and Heritage \\ 7030, Trondheim, Einar Tambarskjelvesgate 2B, Norway \\ E-mail: tone_erlien@hotmail.com
}

\begin{abstract}
A dance museum is a rare reality in Europe. As a result of a wide-range research, the author has found ten museums with different levels of dance dissemination presenting interesting approaches in means of communicating the tacit factor of dance knowledge. She has discovered that visitors engage differently in such communication and a variation in technical equipment gives the transmission of knowledge new expressions. Personal descriptions and pictures from the field will illustrate these means. Moreover, interviews with museum staffs have provided various insights into ideologies and methods. This paper attempts to apply the principles of "New Museology" and Article 18 of the 2003 UNESCO Convention for Safeguarding of the Intangible Cultural Heritage (ICH) to dance presentation techniques in the museums discussed. The red thread in this multi-sited fieldwork amongst different types of museums and dance genres in Europe will be highlighted. Findings and visits prove that there still is a clear division between the traditional museums and new museums in regards to the level of visitors' interaction. In relation to dance and ICH this is a field in its infancy and must be further debated and developed. Interesting points of view come from Museum International articles and New Museology theories and will be the tools of evaluation of what the fieldwork materials present.
\end{abstract}

Keywords: intangible cultural heritage, dance and museum, Europe

\section{FINDINGS FROM 10 MUSEUMS IN EUROPE}

The aim of this thesis fieldwork has been to investigate how institutions and museums in Europe promote and present dance activities and dances through ideas of New Museology and Intangible Cultural Heritage. It may be cultural identities belonging to a range of different groups such as ethnic groups, national groups, local groups or it may be cultural identity of global dance traditions.

The aim is to specify the dissemination ways and pedagogical tools these institutions use in their communication with visitors present in the museum. How the UNESCO Convention supervises projects of dissemination is put as the basic research ground and 
the findings are compared in how their methods coincide with the trends and perspectives in "new museology" and the nominations included in the Best Practice list. In looking for explainable factors of combining museums and ICH, examples have been beforehand drawn from Museum International Articles. My research question is as follow:

To which degree do the museums use ideas and principles drawn from the ICH Convention, Best Practice list and New Museology in their activities and practices of presenting dance heritage? Through the methods of multi-sited fieldwork and to a certain degree participatory observation I intend to find factors and tools for dance dissemination in new technological, pedagogic and participatory ways that function in a global everchanging culturally divers world.

The fieldwork was conducted over a period of 4 weeks, in 4 cities. Five museums were planned beforehand, but as the multi-sited approach was feasible, it ended up with findings from 10 museums. I spent 4 days in each town, Molde, Paris, Sevilla and Stockholm. Two towns gave me a reason to return later to fulfil my research and I am glad I did, taking into account how important a deeper interview proved to be in terms of results. My equipment in the field was a camera, a notebook and prepared questions for the fixed interview arrangements. Tasks in the field came out to be gathering booklets, maps and formal explanations, taking pictures of the different means of dissemination, filming and writing explanations of how the means functioned, taking notes of how the tourists reacted or behaved towards the means and chatting with the information workers about number of visitors and which kinds of tourists are frequently arriving. I had several days at each museum, which allowed me to approach the site differently: informal interviews, watching performances, participant observation as a tourist myself and following guided tours. Looking into archives was offered in one museum.

\section{THEORIES AND METHODS}

The theoretical background for the presented fieldwork is first and foremost grounded in ICH and "new museology", a new trend in museum theories (Black, Hooper-Greenhill). In the UNESCO Convention of ICH Articles 13, 14, 15 and 18 are the relevant ones, the latter concerning the "importance of establishing programs, projects and activities that in a good way promote the intentions and objectives of the 2003 Convention" (UNESCO 2003). The discussion role ICH has in this thesis may be summarized briefly by looking at a few points. The Convention states no direct strategies for how to disseminate intangible cultural heritage, ${ }^{1}$ but has the normative role in measuring factors of how to safeguard. It functions as an international framework and a political tool but the Convention asks nations to make necessary measures to ensure viability, that again should cooperate with approved NGOs. The best practice list ${ }^{2}$ has two examples I want to draw lines to, the Fandango Living Museum in Brazil and Táncház in Hungary ${ }^{3}$. The selections of best practices

\footnotetext{
${ }^{1}$ KURIN 2004

${ }^{2}$ UNESCO $2013 \mathrm{a}$.

${ }^{3}$ UNESCO 2013b, 2013c.
} 
are based on good results from host countries, have to coincide with the Convention and additionally should be feasible in other countries. One interesting point is UNESCO's interest in receiving proposals of cooperation with museums. ${ }^{4}$

Concerning museums in general and their relation to $\mathrm{ICH}$, this is a very recent topic from the $21^{\text {st }}$ century. Few studies deal with how museums work with the implementation of ICH. One very central book is "Intangible heritage and the museum - new perspectives on cultural preservation" by Marilena Alivizatou from 2012, which serves many good examples of work done. As a starting point for the research plan I focused on what role museums play today and in the future, in combining the ICH convention and museum challenges, development and principles. Museums are institutions with a global framework and we see more and more museums advantage new technologies for educational purposes, documentation, management and marketing. Today, they have a good fundament for working with the transmission, viability and promotion of intangible knowledge, as an addition to their preservation, conservation and archival status and techniques. Additionally the museums could serve as a convenient place for testing new technologies for educational tools, documentation, management and marketing. ${ }^{5}$ Relating to new museology, museums need to be open for new trends and constantly changing expectations of guests. ${ }^{6}$ The opposition between "traditional museums" and "new eco museums" is evident.7 In line with Article 15 in the Convention the new museology underlines the important role of the community for sustainable planning and implementation of projects on all levels. ${ }^{8}$

The challenge lies in having to consider the ever-changing aspect of guest's expectations. Several researchers suggest new museology to make a crucial part of this rethinking of strategies with highlighting the relationship between the intangible and tangible. ${ }^{9}$ One point in the right direction is the collaboration between ICOM and UNESCO making curriculum concerning education of museum staff on local level ${ }^{10}$ There is surely a demand for further research concerning limitations and strengths of how museums deal with the subject of intangible cultural heritage in exhibitions, collections and communities, though media, technology and innovation should be applied to adjust the heritage to new contexts and presentation methods. These may be to clarify use and produce meaning in different settings and integrate people oriented processes and expressions in means of dissemination. Dangers in processes like this could be high costs, commercialization, superficial representation and folklorization. ${ }^{11}$

The notion of new museology $y^{12}$ needs a further explanation. It concerns the presentation of the heritage and the following communication with visitors and audience. In a museum setting new museology introduces a holistic adventure from beginning to end, the

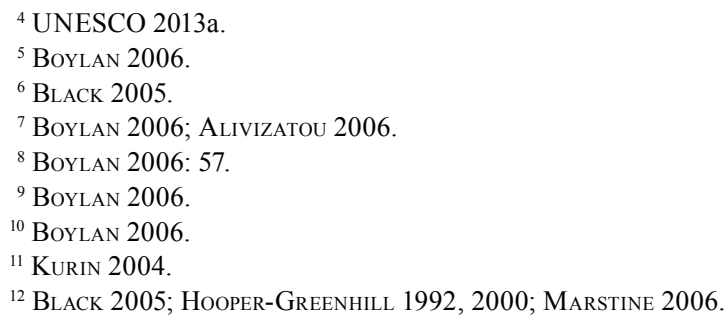


objects play another role, and the means of communication have an educational role and have to adjust to different levels of knowledge, expectations and needs. Exhibitions want to make visitors reflect and react and participate in the visit in a whole new dimension. The post-museum factors are innovative practices to create different perspectives, and exhibitions will get new forms of workshops, events, discussions, storytelling, performances of tacit knowledge and including visitors in real cultural events.

In such a study it is important to include heritage politics and cultural property. WIPO, World Intellectual Property Organization, differentiates between positive protection and defensive protection. The problem arises in copying and borrowing living aspects, which in many cases end up in two versions of one heritage asset, the pre-existing versus the contemporary expression. Positive protection deals with protection over cultural expressions for the possibility to commercialize it, and to ensure that others do not manage. Defensive protection applies in cases of protection against gaining rights over intellectual property. ${ }^{13}$ UNESCO has for a long time cooperated with WIPO in the intellectual property focus on heritage questions and they have produced practical guidelines to institutions in between the global market and the heir community. ${ }^{14}$ The Convention itself does not directly indicate any intellectual property protection as to whom should the expressions belong as private property. ${ }^{15}$ The question of protection, in some part the preservation aspect in the Convention, is realised through documenting and publications. ${ }^{16}$

Methodologically, this ethnographic fieldwork has induced possibilities for different approaches regarding ways of collecting data. Participatory observation ${ }^{17}$ was obviously the most applied method through the whole experience, through participant observation as a tourist. This includes experiences with being at the museum sites, watching performances, trying the technological means of dissemination, witness the traditional means of dissemination and communicating with other tourists. Multi-sited fieldwork ${ }^{18}$ inherits a very clear factor of comparison and looking for the thread that links all sites together has been an evident perception while in the field and in the aftermath. Moving from site to site, all new sites and museums were compared and classified based on the knowledge previous museums gave me. Working with my materials even more comparison has been made to make the path of phenomenon lead into clear descriptions of findings, similarities and differences.

Interviewing in the field proved to be a more efficient method than predicted, and visiting the five museums arranged beforehand resulted in 5 larger interviews with central people to obtain a deeper insight into museum structures and ideologies. It also provided information needed in order to put the material into contexts, answering my questions of why in experiences resulting in reactions from my touristic view. Prepared questions were brought but the informal setting did not demand them when talking led naturally into requested topics. Interviews were conducted with the museum pedagogue at the Museum

\footnotetext{
${ }^{13}$ Wendland, 2004: 101.

${ }^{14}$ BAKKA 1992.

${ }^{15}$ GORE in ICTM 2008.

${ }^{16}$ Wendland 2004.

${ }^{17}$ KaEprler in Buckland 1999.

${ }^{18}$ Marcus 1995.
} 
of Romsdal, Molde; the editor manager at CND - "Centre National de la dance", Paris; the director of the Flamenco Museum, Seville; the dance pedagogue at Skansen, Stockholm and the information manager at Dansmuseet, Stockholm. These informal settings were not recorded in any way, so as to not underline a formal setting for the benefit of better material results. Along with personal notes from touristic experiences and the interviews, pictures, videos and a large amount of secondary sources make up my whole material. Videos are few in hand, caused by bad lighting and hard conditions for filming, as well as prohibitions for filming and photographing at many sites.

\section{MEANS OF DISSEMINATION}

Generally, the 10 visited museums may be divided into two groups, open-air museums and indoor museums. Skansen and the Museum of Romsdal are similar in the way they present dance performances outdoors for tourists coming to open air museums to experience old Scandinavian farming cultures. On the other hand, the division may be in means of disseminating dance, by traditional means or new technological means. The flamenco museum was highly a multimedia museum with a degree on interactive installation, likewise Centre Pompidou presented dance through a multimedia room, CND in Paris presented many ways of benefitting the center, the Ethnographic Museum and Dansmuseet were in the making of means whereby tourists themselves may choose the amount of information, and the Technical Museum presented the only kinaesthetically interactive installation. Most indoor museums present technology as tools to promote the dance material for visitors, though only one makes tourists participate interactively. The interactive factor was contrastingly found in the two open-air museums, in how they invited the tourists to join in at a few simple dances.

Regarding the relation to UNESCO Convention of 2003 may content the division of the museums into two groups; one that included the performance artists of the heritage's heirs, and the other with no involvement of communities. Molde and Skansen represent the former group, the Flamenco museum has a middle role in how their artists are professionals, the remaining museums making up the latter group. Naturally, the presented means are chosen by the museums to cohere with the goals, aims and target group of the museum.

The CND in Paris has a national center role for promoting all genres of dance, and aims both to educate and advise professional dance teachers, as well as to serve the professional and amateur dance audience with performances, workshops and dance source archives in the library/mediateque. In Molde the children dance group's main aim is to have enough kids for everyday performance for tourists throughout the summer season, and with a 20 minutes time limit, the tools of dissemination are restricted to mainly traditional dancing by the children and a couple of dances which include tourists' participation. Both at Skansen and Museum of Romsdal it is the museums' own old tradition of having a folk dance group with a fixed old repertoire that is presented to an audience, and not the content of the dances put in a context. Though in both museums there are nowadays debates whether this thinking is still reliable. Moreover, there are conflicting meanings, 
the museum workers would like to include the dancing into the rest of the main dissemination and contradictorily, the dance group itself is proud of its old unchangeable repertoire. They present their repertoire as for entertaining visitors, and pointing to Dansmuseet as a place for especially interested people and not a place for real cultural experiences.

The traditional means of dissemination were presented through standard photography, paintings and artefacts exhibitions, seen at the Paris Opera, the Flamenco Culture House, the Ethnographic Museum, Dansmuseet and partly at the Flamenco Museum. Dealing with traditional dance cultures and the ballet dance genre, exhibitions consist in a large extent of old or reconstructed costumes, masks or other belonging props. Common for these sites is their way of showing dance works, stereotypes of dance genres and positions through frozen images, modern photographs in black and white, old paintings and drawings, art work and photographs of performances, people and sites. Every museum has it as its purpose to give visitors an idea of context, use, production and meaning. Additionally, large wall charts of text and detailed information are found in relation to the stylized photographs or artefacts. A few videos are displayed, but without any further integration, making sense of what they promote. This was the case in the Ethnographical Museum, connected to the American Indians Pow Wow and African masks, in the basement of Dansmuseet concerning individuals in motion and in the Paris Opera related to the world of ballet. In the Flamenco Culture House in Seville they hold open an exhibition room with photographs, flamenco props and historical overview in text before their evening show with professional dancers. This emerged as a very predictable and small museum where tourists are expected to read and take their time. With less time information would not form content and be useful for the later evening embodied flamenco show. No guiding offered also stresses this factor. As for CND and their museum work, they promote regularly theme-exhibitions with corresponding lectures and conferences, though not object based exhibitions. Fourty text and illustration/photograph planches make up the exhibited material, and booklets are edited and published in relation to the topics. Additionally, these exhibitions tour throughout Europe in French culture houses and other museums.

Performances were seen at the Flamenco Museum, the Museum of Romsdal, Skansen and intertwined in a participant workshop weekend at CND. Additionally, Dansmuseet provides plural performances by professional dancers and musicians in the classic category during school year. Skansen had a Gypsies week with plural performances, has regularly theme weeks during summer, and dance nights for free social dancing with live music. Several museums on my fieldwork offered classes and workshops not in summer season, flamenco classes in Seville, baby dance classes at Dansmuseet in addition to theme-classes for school children, the Museum of Romsdal and Skansen have folk dance group trainings all winter, and CND regularly organize workshops for amateurs. They also allow amateurs and young dancers to participate in the teacher training classes. As mentioned, the folk dance performance at the outdoor museums were similar in content and in what it attempted to communicate.

Interactive means were best promoted at the Technology Museum where children in the sports room could participate kinaesthetically through the dance TV installation. A high level of interaction was already established from the start of the museum and persisted through every room. Children could learn dances through imitating animated dance 
figures on a large screen, gaining point by sensors giving points when correct movement is executed. All kinds of dance genres were presented and the installation was constantly in use. Balance and flexibility exercises were presented and challenged the balance sense. A common overall factor is the learning aspect of every activity at the Technology Museum. A certain level of interaction is also demanded in integrating touch screens in multimedia presented information. This new way of activating visitors was a part of the ideologies at Dansmuseet and the Flamenco Museum in Seville. Former exhibits dance costumes and masks from Africa, Asia and Oceania and wants the audience to take part in the travel of the collector Rolf de Maré. By designing an exhibition with interactive technological means, like pull out boxes of information, visitors may decide how and where to travel in information access. Added to exhibitions, a study center, conferences and lectures are located within the building of Dansmuseet. They call themselves an experiencing knowledge museum, differing from the Flamenco Museum that intentionally promote their context as a simple experiencing site. Latter presents touch screens in learning flamenco styles, steps and technique, and seeking information about touring flamenco dancers' life and properties. Moreover, through 5 rooms of multimedia installations visitors are invited to actively participate in and form their museum experience. Sight, smell, touch and hearing were senses to benefit in walking through the path of flamenco dancing. Although desired to be solely an experiencing museum, knowledge was presented and received in a popular scientific way. ${ }^{19}$ Finally mentioning the Pompidou center with its "Collection nouveau media et film", which gave visitors opportunities to dig into a large archive of dance film, clips, documentaries and performance recordings from a broad range of dance genres and historical happenings. Much time to spend and a level of interest are demanded to fully take advantage of this department of the modern art center.

Undoubtedly, stressing red treads and differences, these museum experiences are seen in relation to each other. The ethnographer's interest makes the path and logical connection. Special attention should be given to how one phenomenon appears differently from various perspectives, or one phenomenon appearing different in a range of social contexts. ${ }^{20}$ Not all examples are proper dance museums and more focus should be paid to how dance is integrated making a supplementary addition to the main aim of dissemination. I have discussed the fieldwork on the basis of division into museum types and of means of dissemination, traditional versus new means of dance presentation. Connected to "new museology" and the ICH Convention preliminary conclusions may summarize the briefly outlined experiences in this text. All museums are debating new trends of how to promote their dance activities for tourists and general visitors, and new means are in production and testing, and in a field of intangible culture it has a wide gap to fill. The interactive level and installations for disseminating tacit knowledge is developing as we speak. Still, this is likewise a field in its infancy requiring further investigation of the pros and cons. Not many informants in the group of museum management are aware of museums' role in implementing the ICH Convention of 2003. The future opportunities for the 10 museums in this multi-sited fieldwork could be involving 3D and motion capture equip-

\footnotetext{
${ }^{19}$ BRoKs 2006.
}

${ }^{20}$ Marcus 1995. 
ment in their installations, collections and exhibitions. In the future work on this topic interesting questions need to be treated; what is the cultural knowledge transmitted ${ }^{21}$ and what do the means of dissemination do to the original embodied knowledge presented? The proposed opposition concerning the use of the notion experience museum versus knowledge museum is to be discussed.

\section{LITERATURE}

Alivizatou, Marilena

2007: Museums and Intangible Heritage: The Dynamics of an "Unconventional relationship". Papers from the Institute of Archaeology 17, 47-57.

2012: Intangible Heritage and the Museum - New Perspectives on Cultural Preservation. Walnut Creek: Left Coast Press Inc.

BAKKA, Egil

1992: Heir, User or Researcher. Basic Attitudes within the Norwegian Revival Movement. In: LoutZAKI, I. (ed.): Proceeding of the 17 $7^{\text {th }}$ Symposium of the Study Group on Ethnochoreology: Dance and Its Socio-Cultural Aspects; Dance and Costume. Nafplion, Greece: Peloponnesian Folklore Foundation, 117-126.

BLACK, Graham

2005: The Engaging Museum - Developing Museums for Visitor's Involvement. New York: Routledge. Boylan, Patrick J.

2006: The Intangible Heritage: Challenge and Opportunity for Museum and Museums Professional Training. International Journal of Intangible Heritage 1, 53-65.

BRoks, Peter

2006: Introduction. In: Understanding Popular Science. Maidenhead: Open University Press, 14.

HoOper-CreEnHILl, Eilean

1992: Museums and the Shaping of Knowledge. London and New York: Routledge-Taylor and Francis Group.

2000: Museums and the Interpretation of Visual Culture. London: Routledge.

ICTM

2008: Intangible Cultural Heritage - Mediation of Knowledge or Nationalistic Competition. In: Proceedings $25^{\text {th }}$ Symposium Kuala Lumpur: ICTM Study Group on Ethnochoreology.

KAEPPLER, Adrienne

1999: The Mystique of Fieldwork. In: Buckland, Theresa J. (ed.): Dance in the Field. Theory, Methods and Issues in Dance Ethnography. Houndmills \& London: Macmillan Press, 13-25.

KurIn, Richard

2004: Safeguarding Intangible Cultural Heritage in the 2003 UNESCO Convention: A Critical Appraisal. In: Museum International, Vol. 56, Nos 1-2. Oxford: Blackwell Publishing.

Marcus, George E.

1995: Ethnography in/of the World System: The Emergence of Multi-Sited Ethnography. Annual Review of Anthropology 24, 95-117.

Marstine, Janet

2006: New Museum Theory and Practice: An Introduction. Malden: Blackwell Publishing.

SKLAR, Deidre

1991: On Dance Ethnography. Dance Research Journal 23(1), 6-10.

2000: Reprise: On Dance Ethnography. Dance Research Journal 32(1), 70-77.

UNESCO

2003: Text of the Convention for the Safeguarding of the Intangible Cultural Heritage. UNESCO Paris, 17 October 2003. Available online: http://www.unesco.org/culture/ich/index.php?lg=en\&pg=00022

${ }^{21}$ SKLAR 1991. 
2013a: Criteria and Timetable for Selection of Register of Best Safeguarding Practices. Available online: http://www.unesco.org/culture/ich/index.php?lg=en\&pg=00300

2013b: Fandango's Living Museum, viewed May 30 ${ }^{\text {th }}$ 2013. Available online: http://www.unesco.org/ culture/ich/index.php?lg=en\&pg=00011\&Art18=00502\#identification

2013c: Táncház Method: A Hungarian Model for the Transmission of Intangible Cultural Heritage. Available online: http://www.unesco.org/culture/ich/index.php?lg=en\&pg=00011\&Art18=00515\# identification

WENDLAND, Wend

2004: Intangible Heritage and Intellectual Property: Challenges and Future Prospects. In: Museum International Vol. 56, Nos 1-2. Malden: Blackwell Publishing. 
PAPERS DEDICATED TO THE $80^{\mathrm{TH}}$ ANNIVERSARY OF GYÖRGY MARTIN'S BIRTH 